\title{
Обґрунтування концепції безперервного вдосконалення національної системи охорони здоров'я України
}

Мета - обґрунтувати концепцію безперервного вдосконалення національної системи охорони здоров'я України в сучасних умовах. Об'єкт дослідження - система охорони здоров'я України. Методи дослідження - бібліосемантичний, концептуального моделювання, колективних експертних оцінок за Дельфійською процедурою, статистичний. Результати. Розроблено концепцію розвитку системи охорони здоров'я України, в якій задекларовано основні цінності щодо охорони здоров'я, сформульовано головну мету, основні цілі/завдання, принципи організації вдосконаленої національної системи охорони здоров'я та розділи стратегії розвитку системи, що базуються на представленій концепції. Висновки. Розроблений проект Концепції є виваженим та погодженим з експертною спільнотою. Документ може бути використаний як основа при розробці подальших документів, які формуватимуть політику в сфері національної охорони здоров'я - стратегії, нормативно-правової бази реформ тощо.

ключові слова: охорона здоров'я, концепція, Україна, Дельфійська процедура.

\section{Вступ}

Міжнародна спільнота сьогодні розглядає здоров'я як першорядний чинник розвитку людства. У Талліннській декларації Європейської міністерської конференції Всесвітньої організації охорони здоров'я «Системи охорони здоров'я для здоров'я та добробуту" (WHO, 2008) зазначено, що “....поліпшення здоров'я не лише являє собою величезну самостійну цінність, але й, завдяки своєму впливу на економічний розвиток, конкурентоздатність та продуктивність праці, сприяє зростанню соціального благополуччя. Високоефективні системи охорони здоров'я сприяють економічному зростанню та підвищенню добробуту». Організація Об'єднаних Націй у своєму документі «Перетворення нашого світу: Порядок денний в галузі сталого розвитку на період до 2030 року» (General Assembly, 2015) надає вирішенню проблеми забезпечення здоров'я та благополуччя ключову роль серед інших цілей сталого розвитку, підкреслюючи, що загальне охоплення послугами охорони здоров'я може сприяти скороченню масштабів бідності, захищаючи людей від однієї з найсерйозніших загроз їх фінансового благополуччя, а позитивні показники здоров'я можуть стимулювати зайнятість та економічне зростання. Крім того, надійні системи охорони здоров'я здатні служити заслоном від соціальних та економічних наслідків спалахів захворювань та інших надзвичайних ситуацій у сфері охорони здоров'я.

В Україні стан здоров'я населення на сучасному етапі розвитку оцінюється як незадовільний. Очікувана тривалість життя при народженні у 2017 р., за даними Державної служби статистики України, становила 72 роки - більше ніж на 9 років менше порівняно з країнами Європейського Союзу і країнами Організації економічного співробітництва і розвитку (ОЕСР) (OECD, 2017; WHO, 2018). Додаткове напруження в демографічній ситуації України створює масовий відтік передусім працездатного населення за межі країни.

Система охорони здоров'я України істотно недофінансована: рівень витрат за паритетом купівельної спроможності (ПКС) на одного мешканця в 2015 р. був у 8,5 раза меншим, ніж у середньому в країнах ОЕСР (469,4 та 4003 дол. США відповідно) і майже вдвічі меншим порівняно з країнами, що розвиваються (800 дол. США за ПКС) (worldbank, 2015; OECD, 2017). При цьому, за даними Державної служби статистики України (2018), частка приватних витрат домогосподарств на охорону здоров'я прогресивно зростає - $338,6 \%$ у 2003 р. до 52,8\% у 2016 р., що в 2,5 раза більше порівняно з країнами ОЕСР - 35 в 2016 р. (OECD, 2017), і створюе серйозні бар'єри в доступі населення до медичного обслуговування.
Рівень задоволеності пацієнтів послугами охорони здоров'я в Україні низький. Лише 10\% громадян оцінюють якість охорони здоров'я в Україні позитивно, більшість (85\%) - як погану чи дуже погану ${ }^{*}$.

Реальні реформи системи охорони здоров'я в Україні розпочалися з великим запізненням порівняно з іншими пострадянськими країнами - майже через два десятиліття після проголошення незалежності (Lekhan V. at al., 2015). За оцінками національних експертів (Лехан В.М. та співавт., 2018), реформи, які проводяться в Україні впродовж останніх 10 років, характеризуються недостатньою системністю та наступністю і носять фрагментарний характер, що значною мірою пов'язано з політичним контекстом; відсутністю стратегічного планування з науково виваженим довгостроковим загальним вектором дій щодо розвитку, який враховує існуючі та потенційні ризики при здійсненні перетворень; наявністю істотних прогалин у нормативно-правовому забезпеченні реформ тощо. Все вищенаведене зумовило необхідність розроблення концепції вдосконалення системи охорони здоров'я України з подальшим опрацюванням стратегії її розвитку.

Мета - обґрунтувати концепцію безперервного вдосконалення національної системи охорони здоров'я України в сучасних умовах.

\section{Об'єкт і методи дослідження}

Об'єктом дослідження є система охорони здоров'я України

У роботі використано методи: бібліосемантичний, концептуального моделювання, колективних експертних оцінок за Дельфійською процедурою (Лехан В.М. та співавт., 2017), статистичний.

\section{Результати та їх обговорення}

На основі поглибленого аналізу ситуації в системі охорони здоров'я України та критичної оцінки процесів перетворень у пострадянських країнах (Rechel B. et al. (Eds.), 2014) із застосуванням методу концептуального моделювання нами розроблено проект концепції безперервного вдосконалення національної системи охорони здоров'я України, в якій визначено основні цінності вдосконаленої національної системи охорони здоров'я, її мету, цілі/ завдання, принципи, а також структуру стратегії, яка повинна бути розроблена на базі цієї концепції, та ключові терміни, застосовані в документі, - глосарій.

*Опитування проведено Інформаційно-аналітичним центром «РЕЙТИНГ ПРО». Опитано 2000 респондентів, період - червень 2015 р. (http://ratinggroup.ua/files/ratinggroup/ reg_files/healthcare_report_072015.pdf). 
Оцінку проекту Концепції проводили методом колективних експертних оцінок за 2-туровою Дельфійською процедурою. У ролі експертів виступили члени Координаційної та Поважної рад Громадської організації «Українська медична експертна спільнота». Необхідна кількість експертів визначена за формулою (Лукичева Л.И., Егорычев Д.Н., 2009):

$$
n \geqslant 0,5 \cdot(0,33 / p+5) \text {, }
$$

де $p-$ помилка результату експертного аналізу $0<\mathrm{p}<1$.

При допустимій помилці експертного аналізу у $5 \%(p=0,05)$ до складу експертної групи повинно входити не менше 6 експертів. У проведеному нами дослідженні експертизу здійснювали 10 осіб. Таким чином, результати розрахунків відповідають рекомендованій кількості експертів для проведення Дельфійської процедури, відповідно до принципу Гештальта і практичних рекомендацій щодо проведення експертного оцінювання у медицині, згідно з якими 6-20 експертів є оптимальною кількістю експертної групи. Рівень компетентності експертів був високим і становив 0,80 , що перевищує критичне значення для компетентності $(0,67 \leqslant M \leqslant 1)$ і свідчить про здатність групи вирішувати поставлені перед нею завдання.

У процесі 1-го туру експертизи членами групи надано низку пропозицій щодо доповнення та зміни окремих складових різних розділів проекту документа. На 2-й тур експертизи представлено скоригований документ.

У результаті, незважаючи на певні розбіжності думок експертів на початку дослідження, після 2-турової експертизи щодо розроблення Концепції коефіцієнт погодженості суджень експертів становив $\mathrm{W}=0,90(\mathrm{p}<0,01)$, коефіцієнт альфа Кронбаха наближався до максимального значення і становив 0,912, що $є$ свідченням досягнутого високого консенсусу.

Нижче представлено остаточний варіант Концепції після досягнення консенсусу експертів.

$$
* * *
$$

Проект

\section{Концепція безперервного вдосконалення} національної системи охорони здоров"я України

Національна система охорона здоров'я України та її безперервне вдосконалення ґрунтуються на визнанні українським суспільством таких основних цінностей:

- людиноцентричність, що має бути відображено у встановленні індикаторів прогресу, пов'язаних зі здоров'ям людини, доступністю для людини необхідних послуг з охорони здоров'я;

- духовність, що має бути відображено у державному пріоритеті дотримання права на життя і здоров'я, який не може бути заперечений, упосліджений чи підмінений іншими, передусім матеріальними, цінностями в діяльності системи охорони здоров'я та інших галузей економіки;

- національна безпека, що має бути відображено увизначенні та постійній актуалізації медико-біологічних, екологічних і техногенних ризиків, утому числі пов'язаних з воєнною загрозою для України, забезпеченні здатності та високої готовності їх подолання.

I. Метою національної системи охорони здоров'я та їїбезперервного вдосконалення є збереження і поліпшення здоров'я громадян України задля загального блага та забезпечення максимального внеску системи охорони здоров'я у відтворення та примноження людського потенціалу/капіталу нації.

II. Досягнення вказаної мети з врахуванням зазначених цінностей передбачає реалізацію таких завдань/цілей, як:

1. Збільшення тривалості та якості життя, що позначиться у:

- збільшенні середньої тривалості життя;

- збільшенні очікуваної тривалості здорового життя при народженні;

- зменшенні загального тягаря хвороб;

- зниженні малюкової смертності.

2. Забезпечення своєчасного, справедливого і рівного доступу громадян до необхідних якісних послуг з охорони здоров'я, що позначиться $y$ :

- зменшенні витрат на лікування у структурі видатків домогосподарств;
- усуненні випадків катастрофічних видатків домогосподарств, пов'язаних із лікуванням;

- забезпеченні для громадян незалежно від місця проживання високої та рівної доступності первинної медичної допомоги на засадах сімейної медицини;

- забезпеченні громадян екстреною медичною допомогою з доїздом у межах 10-20 хв, відповідно до місцевості їх проживання (місто/село);

- збільшенні частки пацієнтів, перш за все дітей, які отримують адекватну стану та індивідуальним потребам, а також своєчасно (у межах терапевтичного вікна) і в повному обсязі комплексну високотехнологічну медичну допомогу;

- збільшенні частки пацієнтів, перш за все дітей, які отримують адекватну стану та індивідуальним потребам медичну реабілітацію і паліативну допомогу в повному обсязі;

- збільшенні частки пацієнтів, перш за все дітей, які отримують адекватну стану та індивідуальним потребам стоматологічну допомогу в повному обсязі;

- досягненні високого рівня забезпеченості практикуючими медичними працівниками за їх категоріями;

- зниженні смертності серед лікарів/медичних працівників до середнього серед загального населення;

- дотриманні вимоги контролюдержави над критичною медикосанітарною інфраструктурою.

3. Забезпечення чутливості до потреб громадян у сфері охорони здоров'я, що проявиться у:

- високому рівні задоволеності послугами з охорони здоров'я (медичним обслуговуванням) та політикою охорони здоров'я.

III. Досягнення мети і цілей потребує розроблення, затвердження, належного ресурсного забезпечення, моніторингу успішності реалізації, а також своєчасної корекції Стратегії безперервного вдосконалення національної системи охорони здоров'я України (далі - Стратегія) на основі слідування таким принципам:

- системного комплексного розвитку та інтегрованості, який слід розуміти як узгодженість змін всіх елементів галузі охорони здоров'я, максимальну інтеграцію їх діяльності, а також координацію змін в інших секторах економіки в інтересах життя і здоров'я людини;

- демонополізації та децентралізації, який слід розуміти як відсутність домінування і монополії будь-яких елементів системи над іншими елементами, за винятком питань національної безпеки;

- доказовості й безпеки, який слід розуміти як використання при виборі варіантів досягнення цілей та розв'язання тих чи інших проблем із проміж різних варіантів таких, які спираються на наукові докази, утому числі щодо безпеки застосування; - соціальної справедливості, що означає зміцнення і охорону здоров'я людей без обмежень з будь-яких ознак або індивідуальних характеристик та забезпечення універсального доступу до якісної медичної допомоги представників всіх соціально-економічних груп;

- паритету відповідальності, який слід розуміти як виважений баланс відповідальності людини, работодавця і держави за індивідуальне здоров'я;

- доступності, який слід розуміти як надання переваги змінам, якіпередбачають досягнення універсального доступугромадян до необхідних послуг з охорони здоров'я;

- вищої якості, результативності та ефективності, який слід розуміти, як надання переваги втручанням, що забезпечують найвищу якість і результативність при мінімальних витратах;

- інноваційності, який слід розуміти як обов'язковість спрямування частини ресурсів на розроблення/виявлення, пілотування, аналіз і мультиплікацію інноваційного досвіду і технологій;

- превентивності, який слід розуміти як надання виваженої переваги втручанням, що запобігають захворюванню чи шкоді здоров'ю над втручаннями, спрямованими на боротьбу із захворюваннями;

- публічності, який слід розуміти як залучення усіх заінтересованих сторін до участі у виробленні та реалізації політики охорони здоров'я, у тому числіпрофспілок, організацій робо- 
тодавців, пацієнтських організацій і організацій професійного самоврядування в охороні здоров'я.

IV. Стратегія складається 3 таких основних розділів:

1. Аналіз основних проблем охорони здоров'я.

2. Розгорнута характеристика основних цілей та підцілей (індикаторів) вдосконалення системи охорони здоров'я з їх кількісним визначенням у часі.

3. Основні завдання.

3.1. Зміцнення громадської охорони здоров'я.

3.2. Формування здорового способу життя.

3.3. Зменшення негативного впливу на здоров'я основних неінфекційних захворювань (органів кровообігу, новоутворень, органів дихання тощо).

3.4. Зменшення негативного впливу на здоров'я основних інфекційних захворювань (туберкульоз, СНІД, дитячі інфекці тощо).

3.5. Поліпшення репродуктивного здоров'я.

4. Основні елементи.

4.1. Управління і лідерство.

4.2. Система фінансування.

4.3. Кадрова політика і освіта.

4.4. Наука та інновації.

4.5. Медичне обслуговування.

4.6. Лікарські засоби, медичні технології та медичні вироби.

4.7. Інформаційні технології.

4.8. Комунікації.

V. Досягнення мети та реалізація завдань/цілей Стратегії ґрунтуються на застосовуванні ціннісно-цільового та компетентнісного підходів задля досягнення максимально ефективного використання людського капіталугалузі та їі інфраструктури.

При виборі способів досягнення мети і цілей вибір варіанта рішення для включення у Стратегію здійснюється на підставі моделювання і порівняння альтернатив за їх наявності.

\section{VI. Глосарій}

Очікувана середня тривалість життя при народженні загальноприйнятий міжнародний індекс (інтегральний показник), який характеризує усереднений очікуваний інтервал між народженням і смертю для даного покоління і становить число років, яке в середньому належить прожити поколінню народжених в даному році за умови, що протягом життя покоління зберігаються повікові показники смертності даного року.

Глобальний тягар хвороб - загальноприйнятий міжнародний індекс (disease adjusted life year - DALY), який характеризує втрати здорових років життя в результаті передчасної смертності та інвалідності.

Очікувана тривалість здорового життя - загальноприйнятий міжнародний індекс (health life expectancy - HALE), якийхарактеризує число років здорового життя, на які люди можуть розраховувати в разі незмінності нинішніх умов.

Малюкова смертність - один із базових показників, що характеризує здоров'я, оцінює рівень смертності серед дітей віком до 1 року.

Критична медико-санітарна інфраструктура - структурн елементи національної системи охорони здоров'я, що забезпечують постійну і безперервну готовність реагування на медикобіологічні, екологічні й техногенні ризики, у тому числі пов'язані з воєнною загрозою для України.

\section{Висновки}

1. Розроблений проект Концепції є виваженим та погодженим з експертною спільнотою.

2. Цей документ може бути використаний як основа при розробці подальших документів, які формуватимуть політику у сфері національної охорони здоров'я - стратегії, нормативно-правової бази реформ тощо.

\section{Список використаної літератури}

Державна служба статистики України (2018) Національні рахунки охорони здоров'я (НРО3) України у 2016 році. Статистичний бюлетень. Київ, $172 \mathrm{c}$.

Лехан В.М., Волчек В.В., Крячкова Л.В., Заярський М.І. (2017) Застосування колективних експертних оцінок за дельфійською процедурою в соціально-медичних дослідженнях. Україна. Здоров'я нації, 1(42): 62-68.
Лехан В.М., Крячкова Л.В., Заярський М.І. (2018) Аналіз реформ охорони здоров'я в Україні: від здобуття незалежності до сучасності. Україна. Здоров'я нації, 4(52): 5-11.

Лукичева Л.И., Егорычев Д.Н. (2009) Управленческие решения. Омега, Москва, 383 с.

General Assembly (2015) Resolution adopted by the General Assembly on 25 September 2015 (http://www.un.org/ga/search/view_doc.asp?symbol=A/ RES/70/1\&Lang=E).

Lekhan V., Rudiy V., Shevchenko M.et al. (2015) Ukraine: Health system review. Health Systems in Transition, 17(2): 1-153.

OECD (2017) Health at a Glance 2017 (http://dx.doi.org/10.1787/health_ glance-2017-en)

Rechel B., Richardson E., McKee M. (Eds.) (2014) Trends in health systems in the formerSoviet countries (http://www.euro.who.int/_data/assets/ pdf file/0019/261271/Trends-in-health-systems-in-the-former-Soviet-countries. pdf?ua=1).

worldbank (2015) Current health expenditure per capita, PPP (current international \$) (https://data.worldbank.org/indicator/SH.XPD.CHEX.PP.CD)

WHO (2008) European Ministerial Conference on Health Systems «Health Systems, Health and Wealth» (http://www.euro.who.int/ data/assets/pdf file/0008/88613/E91438.pdf?ua=1).

WHO (2018) European Health for All database (HFA-DB) (https://gateway.euro. who.int/en/datasets/european-health-for-all-database/).

\section{Обоснование концепции непрерывного совершенствования национальной системы здравоохранения Украины \\ К.А. Надутий, В.Н. Лехан, И.В. Найда}

Резюме. Цель - обосновать концепцию непрерывного усовершенствования национальной системы здравоохранения Украины в современных условиях. Объект исследования - система здравоохранения Украины. Методы исследования - библиосемантический, концептуального моделирования, коллективных экспертных оценок по Дельфийской процедуре, статистический. Результаты. Разработана концепция развития системы здравоохранения Украины, в которой задекларированы основные ценности здравоохранения, сформулирована главная цель, основные цели/задачи, принципы организации усовершенствованной национальной системы здравоохранения и разделы стратегии развития системы, основанные на представленной концепции. Выводы. Разработан проект Концепции является взвешенным и согласованным с экспертным сообществом. Документ может быть использован в качестве основы при разработке последующих документов, которые будут формировать политику в сфере национального здравоохранения - стратегии, нормативно-правовой базы реформ и тому подобное.

Ключевые слова: здравоохранение, концепция, Украина, Дельфийская процедура.

\section{Substantiation of the concept of continuous improvement the national health system of Ukraine}

\section{K.O. Nadutiy, V.M. Lekhan, I.V. Nayda}

Summary. The goal is to substantiate the conception of continuous improvement of the national health care system of Ukraine in modern conditions. The object of research - health system of Ukraine. Methods. Bibliographic, conceptual modeling, Delphi, medico-statistical methods were used. Results. The concept of development of the health system of Ukraine has been developed. It declares the core values of health care, formulates main goal, basic goals/objectives, principles for organizing an improved national health system, and sections of the system development strategy based on the presented concept. Conclusions. The developed draft of the Concept is balanced and agreed with the expert community. The document can be used as the basis for the development of the following documents that shape the policy in the field of national health care - strategies, regulatory framework of reforms, and the like.

Keywords: healthcare, conception, Ukraine, Delphi procedure.

\section{Адреса для листування:}

Валерія Микитівна Лехан

49000, Дніпро, вул. Володимира Вернадського, 9

Державний заклад «Дніпропетровська медична академія М03 України» E-mail:v.n.lexan@gmail.com 